\title{
Education in Medicine Journal
}

\section{Nursing students' attitudes towards HIVIAIDS: Ağrı, Istanbul and Mersin samples from}

Turkey

\section{Şerife Gonca Zeren ${ }^{1}$. Devrim Alıcı ${ }^{2}$, Fatma $\mathrm{Ay}^{3}$}

${ }^{1}$ Yıldiz Technical University, Faculty of Education, Psychological Counseling and Guidance, Davutpasa, Esenler İstanbul, Turkey. ${ }^{2}$ Mersin University, Faculty of Education, Department of Educational Sciences, Yenisehir Campus, 33169 Mersin, Turkey. ${ }^{3}$ Istanbul University, Faculty of Health Sciences, İstanbul, Turkey.

\section{Abstract}

Objective: This study investigates nursing students'attitudes towards HIV/AIDS in three different provinces of Turkey. The chosen provinces are İstanbul, the largest and most crowded city of Turkey; Ağrı, which is located in the further east of Turkey with socio-economic disadvantages and finally Mersin, one of the most important port cities of Turkey. Method: A total of 230 nursing students formed the population of this research. The research data was compiled through personal information forms and HIV/AIDS attitude inventory. HIV/AIDS Attitude Inventory (henceforth HAAI) is a 19-item 4 point Likert-type scale.Percentages and mean scores were executed and computed during data analysis. Students' sociodemographic data were also analyzed. The following steps were followed for the analysis of attitude levels about HIV/AIDS through HAAI. Result: The results of the research reveal that nursing students in general have a positive attitude towards HIV/AIDS. No considerable difference was found between the academic background, marital status, having previous sexual experience or not, having a patient with HIV/AIDS, and caring for a person with HIV/AIDS or not in the different grade levels of the nursing school and their attitudes about HIV/AIDS. It was identified that nursing students with high anxiety level about caring for someone with HIV/AIDS have higher level of attitudes towards HIV/AIDS than those with lower levels of anxiety about this issue. Conclusion: This research was conducted in three different cities of Turkey and its results cannot be generalized to the country. In spite of its limitations, the results of this research can help reach some important and functional clues regarding nursing education. The nurses should be educated about this subject at universities to gain positive attitudes towards HIV/AIDS patients.

Keywords

HIV/AIDS, nursing students, attitudes towards HIV/AIDS, nursing.

How to cite this article?

Zeren, S.G., Alıc1, D., \& AY, F. (2012). Nursing students' attitudes towards HIV/AIDS: Ağr1, Istanbul and Mersin samples from Turkey. Education In Medicine Journal, 4(1). DOI:10.5959/eimj.v4i1.13 


\section{Education in Medicine Journal}

2012, VOL 4 ISSUE 1

DOI:10.5959/eimj.v4i1.13

\section{Introduction}

HIV (Human Immunodeficiency Virus) and AIDS (Acquired Immunodeficiency Syndrome) caused by this virus is one of the most widespread diseases of the world. In many countries today studies to find new and effective cures for HIV/AIDS are being conducted,and necessary medical interventions are suggested to improve and increase the life span of patients with HIV/AIDS. People with HIV/AIDS have gradually grown out of the label "waiting for the death", and started to be named as individuals "living with HIV/AIDS". As a result of this change, people with HIV/AIDS have become individuals who benefit from the health systems of their countries regularly.

First cases of HIV/AIDS in Turkey were reported in 1985 . The number of HIV/AIDS cases which was 2 in 1985 has increased over the years, to 5224 in 2011 (1). Globally there were an estimated 34 million people [31.6 million - 35.2 million] living with HIV in 2010, and since 2005, AIDS-related deaths decreased from 2.2 million [2.1 million - 2.5 million] to 1.8 million [1.6 million - 1.9 million] in 2010 (2).

Turkey is a country with a young population, with half of its population under $25(3,4)$. The rapidly developing tourism and urbanization in Turkey, the high number of its population working abroad and the increase in use of intravenous substances are stated to be the factors in HIV/AIDS spread $(4,5)$. In addition to this, the role of sex labourer foreign women who come to Turkey following the disintegration of Soviet Union is also discussed as one of the major factors for the spread of HIV/AIDS. (6). Because of the factors stated above, it is thought that maintenance and expansion of preventive measures for HIV/AIDS in Turkey is important in decreasing the pace of its spread.
There have been various studies in recent years which explore attitudes towards HIV/AIDS in Turkey. One of these studies (7) takes as its subject the knowledge and attitudes of medical students towards HIV/AIDS. The results of this study rendered an unsufficient level of information on part of these students as well as a negative attitude. Another study (8) revealed similar findings, pointing out insufficient knowledge and negative attitudes towards HIV/AIDS.

As a result of the social prejudice resulted by the realistic and unrealistic fear of society towards HIV/AIDS, and its discriminative approach to infected people (9) makes life with AIDS difficult for such people and their relatives. These people and their relatives can live in shame for being subject to discriminative and labeling approach by the society. When such an approach is existent in society, health professionals are expected to harbour a positive approach to HIV/AIDS, free from any discrimative / labeling perspective. The attitudes, values and beliefs of health professionals are very important since they determine their approach to people with HIV/AIDS.

Nurses are one of the largest groups in health professionals who take care of patients with HIV/AIDS and are in close contact with them. That is the reason why there have been many studies in various countries in the world on the attitudes of nurses and nursing students towards HIV/AIDS (10-19) recently.

The reviews of some studies reveal that nurses and nursing students have both positive and negative attitudes. One of them (11) points out that almost half of the nursing students are afraid of taking care of a person with HIV/AIDS, while $12 \%$ are unwilling to be assigned to serve people with HIV/AIDS because of feeling insufficient in meeting their physical needs, and similarly $19 \%$ refrain from attending people with HIV/AIDS owing to the 


\section{Education in Medicine Journal}

2012, VOL 4 ISSUE 1

DOI:10.5959/eimj.v4i1.13

psychological needs of HIV/AIDS patients. The same study shows that $92 \%$ or nursing students do not refuse to be assigned to patients with HIV/AIDS, $48 \%$ think that such assignment must be voluntary-based and $96 \%$ have positive attitude regarding caring for people with HIV/AIDS.

Another study (18) stresses that the attitudes of nurses who have previously experienced looking after patients with HIV/AIDS are significantly different in a positive way from those who have not had such experience. In Turkey, there is limited amount of research which investigates attitudes of nurses and nursing students towards HIV/AIDS. One such study (20) explains that the attitudes of nursing, midwifery and health industry students towards HIV/AIDS are generally positive. Another study (21) reports negative and contradictory statements in the attitudes of nursing and midwifery school students towards HIV/AIDS.

Positive attitudes of nurses towards people with HIV/AIDS help them not only improve these patients' both physical and psychological well-being. The researchers have decided to work on this issue because of the great importance of positive attitudes of nurses towards HIV/AIDS, as well as limited number of relevant research in Turkey.

The aim of this study is to investigate nursing students'attitudes towards HIV/AIDS in three different provinces of Turkey. The chosen provinces are istanbul, the largest and most crowded city of Turkey; Ağrı, which is located in the further east of Turkey with socioeconomic disadvantages and finally Mersin, one of the most important port cities of Turkey.

\section{Method}

\section{Study Sample}

This research was conducted in 2006-2007 academic year with students in nursing schools Istanbul University Bakırköy Health College (IUBHC), Ağrı İbrahim Çeçen University Health College (AICUHC) and Mersin University Health College (MUHC). Of the total of 588 students studying in these three colleges, 230 were chosen on a random and layered basis. All of the participants were females.

\section{Instrument}

Personal Information Form (PIF). This form contains some demographical information about students such as their class, marital status, etc. There are also questions about whether they have attended any seminars, conferences, meetings etc. about HIV/AIDS, whether they have a friend, relative, etc. with HIV/AIDS, whether they have cared for a patient with HIV/AIDS and whether they have concerns about caring for a patient with HIV/AIDS.

\section{HIV/AIDS Attitude Inventory (HAAI)}

HIV/AIDS Attitude Inventory is standardized, a Likert-type scale which has 19 items (22). HAAl comprises sub-sections titled "Avoidance towards people with HIV/AIDS", "Sexual biases", "Sexual risk taking". The items in the inventory are responded with the choices "not suitable", "partly suitable", "mostly suitable" and "totally suitable". The maximum possible points received is 88 while the lowest number of points is 22 . Higher points from the inventory point to positive attitudes towards HIV/AIDS and low points demonstrate negative attitudes towards HIV/AIDS. 


\section{Education in Medicine Journal}

2012, VOL 4 ISSUE 1

DOI:10.5959/eimj.v4i1.13

The validity of HAAI is enabled by factor analysis and internal criteria verification. The Cronbach $\alpha$ reliability coefficient of HAAI is 0,79 , and the reliability coefficients of subsections are 0,$74 ; 0,70$ and 0,72 , respectively. The test-retest reliability coefficients of HAAI for sub-sections are found to be 0,$77 ; 0,80$ and 0,73 respectively (22). We further warrant that permission for HAAl has been obtained from author.

\section{Data Analysis}

Percentages and mean scores were used during data analysis. Students' sociodemographic data were expressed in percentages. The following steps were followed to analyse attitude levels about

\section{The Attitudes of Nursing Students Towards HIV/AIDS}

Looking at the distribution of responses to HAAI, one student's responses were excluded from the analysis because of their extreme values. Some statistics regarding the distribution of HAAl points revealed that, although the average (70.40) and the median (71.00) are close, the average is lower, and the distortion coefficient $(-0.225)$ and lowness coefficient $(-0.446)$ are negative values and are close to 0.00 . Considering this data, it can be said that the distribution is distorted to the left and is somewhat less distributed than normal. In the normal distribution analysis through Kolmogorov Smirnov test, it was found that the distribution of attitude level points is not normal $(z=0.070 ; p>0.05)$. The lowest point obtained is 47.00 , and the highest point is 85.00 . Whe considering that the lowest possible points in the inventory is 22.00 and maximum points is 88.00 , it can be said that students generally have a positive attitude towards HIV/AIDS. Cronbach $\alpha$ reliability of the points is quite high (0.75).
HIV/AIDS through HAAI. Looking at the distribution of responses to HAAl, one student's responses were excluded from the analysis because of their extreme values. In the data analysis we used Kolmogorov Smirnov test, Kruskall Wallis test, and Mann Whitney $U$ test.

\section{Result}

\section{Sample Characteristics}

The demographic characteristics of the students are shown in Table 1 . All of the participating students were women. As seen on Table 1, most of the students were single and did not have sexual experience.

In order to analyze whether students' HIV/AIDS attitude levels vary according to the university of study, the normality of the points distribution for each group was analyzed through Kolmogorov Smirnov test and it was found that the distribution of HAAl points of students from MUHC is not normal (K$\mathrm{S}=0.121 ; \mathrm{p}<0.05)$. The mean values and standard deviation of HIV/AIDS attitude level points of students from the three universities are given in Table 2 .

According to Table 2, the mean atittude level points of MUHC students are higher than those studying at the other two schools. Kruskall Wallis test rendered that there is indeed a meaningful difference between the HAAl points of students studying at different universities $\left(\chi^{2}=6.257 ; p<0.05\right)$. In other words, it can be said that attitudes of participating students towards HIV/AIDS vary from one university to another. As a result of the Mann Whitney $U$ test for a binary comparison in order to determine difference between which groups caused the overall difference, MUHC students were identified to have higher atittude level points than the students in the other two universities. 


\section{Education in Medicine Journal}

2012, VOL 4 ISSUE 1

DOI:10.5959/eimj.v4i1.13

The differences observed in the students' HAAl points were analyzed by taking into consideration the low levels of HAAI (See Table 2).

Table 2 shows that in the sub-sections of "Avoidance towards people with HIV/AIDS" and "Sexual Biases" MUHC students have higher attitude level averages and in the "Sexual Risk-Taking" sub-section, IUBSY students have higher attitude levels than students from other universities.

In order to determine whether these differences are meaningful in the statistical sense, Kruskall Wallis test was used, and as a result of the analysis it was seen that in the "Avoidance towards people with HIV/AIDS" sub-section of HAAl, there are differences between attitude level points of students from different universities $\left(\chi^{2}=12.457\right.$; $p<0.05)$, and the differences observed in the When the statistics in Table 3 are reviewed, the average attitude level points of students from three universities in their fourth year is lower than those of students studying at the other grade levels; and that the average attitude level points of students in their second and third year are very close. Kruskall Wallis test was used in analyzing the meaningfulness of these differences between mean values. The result of the analysis rendered that the differences between HAAI attitude level point averages of students in different class levels are not statistically telling $\left(\chi^{2}=2.664 ; p>0.05\right)$. In other words, studying in different class levels do not cause any difference in their attitudes towards HIV/AIDS.

Table 3 shows that in AICUHC students, freshman students have the highest attiude level point average; followed by students in their fourth, third and second years. In IUBY students, students in their second year have the highest attitude level point average, followed by students in their first, fourth and other sub-sections are not meaningful. Mann Whitney $U$ test was used for disassociated samplings in order to determine the difference between what two groups lead to the overall difference in the sub-section of "Avoidance towards people with HIV/AIDS", and MUHC students were seen to have higher attitude level points than IUBHC students $(U=3091.50 ; p<0.05)$.

In order to determine whether the attitudes of students towards HIV/AIDS demonstrate meaningful differences according to class levels, firstly the normality of points distribution for each class level was analyzed through Kolmogorov Smirnov test. The result of the test revealed that the distribution of HAAl points of students in their first year is not normal ( $\mathrm{K}-\mathrm{S}=0.128 ; \mathrm{p}<0.05)$. The mean values and standard deviations in the HAAI points of students at different class levels are given in Table 3. third year. In MUHC students, students in their third year have the highest attitude level points average followed by students in their second, first and fourth year. Kruskall Wallis test was used to determine whether these differences between the averages of attitude level points are statistically telling. The analysis revealed that HAAI points of MUHC students vary according to class levels $\left(\chi^{2}=12.954 ; p<0.05\right)$. As a result of the Mann Whitney $U$ test to identify the difference between what class levels is the cause of the difference observed, it was found that MUHC second and third year students have higher attitude level points than the fourth year students and that third year students have higher values than first year students.

The differences between the attitudes of students towards HIV/AIDS are also analyzed related to marital status, sexual experience, previous experience of looking after a patient with HIV/AIDS, anxiety for looking after a patient with HIV/AIDS (see Table 4). 


\section{Education in Medicine Journal}

2012, VOL 4 ISSUE 1

DOI:10.5959/eimj.v4i1.13

According to Table 4, the attitude level points of married students were higher than those of single students, the points of students with previous sexual experience are higher than those of students who do not have previous sexual experience and the average points of students who have previous experience of looking after a patient with HIV/AIDS are higher than those who do not. Mann Whitney $U$ tests revealed that the differences observed were not meaningful $\left(U_{\text {marital }}\right.$ status $=729.50$; $p>0.05 ; \quad U_{\text {sexual }}$ experience $=1127.50 ; \quad p>0.05$; $U_{\text {previous experience with patient } w \text { HIV/AIDS }}=3390.50$; $p>0.05)$.

It is striking to see in Table 4 that students who state that they are anxious about taking care of a person with HIV/AIDS have lower averages in their attitude level points. Mann Whitney $U$ test revealed that students who have a higher level of anxiety in looking after a person with HIV/AIDS have higher attitude level points than those with a lower level of anxiety in looking after a person with HIV/AIDS (U=3873.50; $p<0.05)$.

\section{Discussion}

The positive attitudes of health staff (especially nurses) regarding HIV/AIDS have an important role on the quality of care proivded for HIV/AIDS individuals. In this respect, it is believed that nurses who adopt positive attitudes towards HIV/AIDS during their education are likely to be more efficient during their practice period. In this study, it is concluded that the attitude of nursing students towards HIV/AIDS who participated in this research is positive. The positive attitudes towards HIV/AIDS lead to respectful attitudes towards patients and their relatives. This respect not only increases the life quality of HIV/AIDS patients, but also provides better conditions for them to feel at ease and enable them to benefit from the health care services in the best way possible.
According to some research findings about the attitudes of nurses and nursing students towards HIV/AIDS $(11,12,15,20,23)$, the attitude of nurses or nursing students is positive. These findings rendered the same results with the results of such research. However, when certain research findings were examined, the attitudes of nurses or nursing students towards HIV/AIDS were negative $(7,16,18,21,24)$. This is related to the society's negative attitudes towards HIV/AIDS and its reflection on nurses or nursing students. Oyeyemi et al. (2006) believe that the negative attitudes of nurses result from their fear of HIV/AIDS and social implications. Mbanya et al. (2001) emphasize that only $50,5 \%$ of nurses adopt positive attitudes. When the comments of the patients were asked about the attitude of nurses in the same research, most of them said that they did not observe negative feelings such as disgust or HAAI.

In this research, attitudes of MUHC students towards HIV/AIDS are different than those of students in the other two universities. This difference can be explained by the HIV/AIDS training provided to MUHC students. This training is given in the second and third years and not in the fourth year. As a result of this, MUHC second and third year students display higher level attitudes compared to fourth year students. On the other hand, the attitude levels of third year students are higher than the first year students that can also be explained by this training. A similar training (HIV/AIDS training) has been applied for IUBHC students. The effect of this training on the attitude scores towards HIV/AIDS has been reflected in Sexual Risk Taking section. This sub-section has showed that the students of this university have higher attitude scores than the other students who have participated in the research.

According to findings, 126 students (55.2\%) stated that they would be anxious about the 


\section{Education in Medicine Journal}

2012, VOL 4 ISSUE 1

DOI:10.5959/eimj.v4i1.13

HIV/AIDS care. These findings were similar to the findings of another study (25). However, it was also mentioned in the research that they were both anxious and positive while working. The results showed that the students who are more anxious about the care of HIV/AIDS patients show more attitudes than the students who are less anxious worried. While obtaining data for this research, the students were asked to desrcibe the reasons of their anxiety, if they are anxious about the care of a HIV/AIDS patient. The most popular answer is "although the precautions are taken, it is still contagious". The other reasons given for this anxiety are "inappropriate working conditions", "not being ready to care a HIV/AIDS patient" (psychological factors), "feeling insufficient to help the patient", "fear of making a mistake", "hesitation to take responsibility."

This research revealed that there is not a meaningful difference between the attitudes towards HIV/AIDS of students who are single or married, who have sexual experience or not, and who have previously cared for a patient with HIV/AIDS or not. The lack of difference between attitudes of single or married students is parallel to the findings in another study (11). In addition, there is no difference between the attitudes of the students who have / do not have previous experience with a HIV/AIDS patient. This result contradicts with the results of another study which reports that the nurses who have experiences in taking care of HIV/AIDS have more positive attitudes (18).

\section{Conclusion}

This research is has been conducted in three different cities of Turkey and its results are not applicable for other cities. In spite of its limitations, the results of this research can offer some important and functional clues regarding nursing education. The nurses should be educated about this subject at the university to gain positive attitudes towards HIV/AIDS patients. The lessons which give importance to self- judgment and make them realize their own attitudes will be beneficial. The nurses who have an important role in society and health education should be informed about HIV/AIDS during their professional education. They should also apply this information. By doing this, nurses can help change social prejudices and can guide the individual or the family.

In this research, the attitudes of nursing students towards HIV/AIDS have been examined and it is concluded that these attitudes have been generally positive. The attitudes of nurses can also be examined with the help of another study, the attitudes of nurses can be examined from a different perspective, from that of HIV/AIDS patients, and their perception of nurses' attitudes towards them. Thus, candidate nurses who are sensitive to cultural differences can be trained.

Only female students have participated in this research. This is not a pre-planned situation. Only female students have been allowed in nursing faculties in Turkey until recently. In the future, the research can focus on the male nurses and the attitudes of male nursing students towards HIV/AIDS. By this way, it can be examined whether or not there is a relationship between gender differences and attitude.

This research can shed light on the attitudes of nursing students towards HIV/AIDS in Turkey. These results aren't necessarily generalizable to the general nursing students. But nursing which is one of the important professions has a key role in the protection of social health and awareness. It is hoped that this research will help in preventive studies 


\section{Education in Medicine Journal}

2012, VOL 4 ISSUE 1

DOI:10.5959/eimj.v4i1.13

and formation of national policies regarding HIV/AIDS in Turkey.

\section{Clinical Consideration}

- The positive attitudes of health staff (especially nurses) regarding HIV/AIDS have an important role on the quality of the care.

- Nurses can help change social prejudices about HIV/AIDS and can guide the individual or family.

Table 1: Distribution of Student' Individual and Professional Characteristics

\begin{tabular}{|c|c|c|}
\hline Variables & $\mathrm{n}$ & $\%$ \\
\hline \multicolumn{3}{|c|}{ Marital status } \\
\hline Married & 8 & 3.5 \\
\hline Single & 222 & 96.5 \\
\hline \multicolumn{3}{|c|}{ Sexual Experince } \\
\hline Yes & 15 & 6.5 \\
\hline No & 215 & 93.5 \\
\hline \multicolumn{3}{|c|}{ Participation seminars, conferences and similar about HIV/AIDS } \\
\hline Yes & 152 & 66.1 \\
\hline No & 80 & 33.9 \\
\hline \multicolumn{3}{|c|}{ Desire to participate in the seminars, conferences and similar abou } \\
\hline \multicolumn{3}{|c|}{ HIV/AIDS } \\
\hline Yes, I do & 220 & 95.7 \\
\hline No, I dont & 10 & 4.3 \\
\hline \multicolumn{3}{|c|}{$\begin{array}{l}\text { Become knowledgeable about HIV / AIDS to the professional } \\
\text { perspective is required. }\end{array}$} \\
\hline Yes & 228 & 99.1 \\
\hline No & 2 & 0.9 \\
\hline \multicolumn{3}{|c|}{$\begin{array}{l}\text { I gave care to one of the person that suffering from HIV / AIDS, } \\
\text { previously. }\end{array}$} \\
\hline Yes & 41 & 17.8 \\
\hline No & 189 & 82.2 \\
\hline \multicolumn{3}{|c|}{ I have been in close contact with one of person with HIV / AIDS } \\
\hline Yes & 16 & 7.0 \\
\hline No & 214 & 93.0 \\
\hline \multicolumn{3}{|c|}{$\begin{array}{l}\text { I feel anxiety for caring one of the person that suffering from HIV / } \\
\text { AIDS }\end{array}$} \\
\hline Yes & 127 & 55.2 \\
\hline No & 103 & 44.8 \\
\hline
\end{tabular}




\section{Education in Medicine Journal}

2012, VOL 4 ISSUE 1

DOI:10.5959/eimj.v4i1.13

Table 2: Statistics on Students' scores HATE and Lower Dimensions: Mean Scores and Standard Deviations $(\mathrm{N}=230)$

\begin{tabular}{|c|c|c|c|}
\hline HIV/AIDS Attitude & $\mathbf{n}$ & Mean & SD \\
\hline \multicolumn{4}{|l|}{ Universities } \\
\hline $\begin{array}{l}\text { Ağrı İbrahim Çeçen University School for Health } \\
\text { Sciences, Nursing Department }\end{array}$ & 42 & 68.81 & 8.07 \\
\hline $\begin{array}{l}\text { İstanbul University Bakırköy School for Health } \\
\text { Sciences, Nursing Department }\end{array}$ & 97 & 69.64 & 7.35 \\
\hline $\begin{array}{l}\text { Mersin University School for Health Sciences, Nursing } \\
\text { Department }\end{array}$ & 90 & 71.96 & 8.14 \\
\hline \multicolumn{4}{|l|}{ Lower Dimensions } \\
\hline \multicolumn{4}{|l|}{ To avoidance with person that suffering from HIV/AIDS } \\
\hline $\begin{array}{l}\text { Ağrı Ibrahim Çeçen University School for Health } \\
\text { Sciences, Nursing Department }\end{array}$ & 42 & 23.70 & 4.56 \\
\hline $\begin{array}{l}\text { İstanbul University Bakırköy School for Health } \\
\text { Sciences, Nursing Department }\end{array}$ & 97 & 22.99 & 4.74 \\
\hline $\begin{array}{l}\text { Mersin University School for Health Sciences, Nursing } \\
\text { Department }\end{array}$ & 90 & 25.29 & 4.70 \\
\hline \multicolumn{4}{|l|}{ Sexual stereotypes } \\
\hline $\begin{array}{l}\text { Ağrı Ibrahim Çeçen University School for Health } \\
\text { Sciences, Nursing Department }\end{array}$ & 42 & 19.92 & 3.55 \\
\hline $\begin{array}{l}\text { İstanbul University Bakırköy School for Health } \\
\text { Sciences, Nursing Department }\end{array}$ & 97 & 20.60 & 2.91 \\
\hline $\begin{array}{l}\text { Mersin University School for Health Sciences, Nursing } \\
\text { Department }\end{array}$ & 90 & 21.09 & 3.35 \\
\hline \multicolumn{4}{|l|}{ Taking Sexual Risk } \\
\hline $\begin{array}{l}\text { Ağrı İbrahim Çeçen University School for Health } \\
\text { Sciences, Nursing Department }\end{array}$ & 42 & 25.18 & 2.13 \\
\hline $\begin{array}{l}\text { İstanbul University Bakırköy School for Health } \\
\text { Sciences, Nursing Department }\end{array}$ & 97 & 26.05 & 1.67 \\
\hline $\begin{array}{l}\text { Mersin University School for Health Sciences, Nursing } \\
\text { Department }\end{array}$ & 90 & 25.58 & 2.26 \\
\hline
\end{tabular}




\section{Education in Medicine Journal}

2012, VOL 4 ISSUE 1

DOI:10.5959/eimj.v4i1.13

Table 3: The students' attitudes that stay different class about HIV/AIDS: Mean Scores and Standard Deviations ( $\mathrm{N}=230)$

\begin{tabular}{|c|c|c|c|c|}
\hline Year & & $n$ & Mean & SD \\
\hline \multirow[t]{4}{*}{$1^{\text {st }}$ Year } & & 58 & 70.43 & 7.44 \\
\hline & $\begin{array}{l}\text { Ağrı İbrahim Çeçen University School for Health Sciences, } \\
\text { Nursing Department }\end{array}$ & 12 & 71.45 & 6.55 \\
\hline & $\begin{array}{l}\text { İstanbul University Bakırköy School for Health Sciences, } \\
\text { Nursing Department }\end{array}$ & 25 & 69.88 & 7.67 \\
\hline & $\begin{array}{l}\text { Mersin University School for Health Sciences, Nursing } \\
\text { Department }\end{array}$ & 21 & 70.51 & 7.92 \\
\hline \multirow[t]{4}{*}{$2^{\text {nd }} Y e a$} & & 58 & 71.03 & 7.80 \\
\hline & $\begin{array}{l}\text { Ağrı ibrahim Çeçen University School for Health Sciences, } \\
\text { Nursing Department }\end{array}$ & 10 & 65.10 & 8.43 \\
\hline & $\begin{array}{l}\text { İstanbul University Bakırköy School for Health Sciences, } \\
\text { Nursing Department }\end{array}$ & 25 & 70.68 & 6.50 \\
\hline & $\begin{array}{l}\text { Mersin University School for Health Sciences, Nursing } \\
\text { Department }\end{array}$ & 23 & 73.99 & 7.58 \\
\hline \multirow{4}{*}{$3^{\text {rd }}$ Year } & & 55 & 71.07 & 8.32 \\
\hline & $\begin{array}{l}\text { Ağrı İbrahim Çeçen University School for Health Sciences, } \\
\text { Nursing Department }\end{array}$ & 10 & 67.44 & 3.36 \\
\hline & $\begin{array}{l}\text { İstanbul University Bakırköy School for Health Sciences, } \\
\text { Nursing Department }\end{array}$ & 24 & 68.37 & 8.52 \\
\hline & $\begin{array}{l}\text { Mersin University School for Health Sciences, Nursing } \\
\text { Department }\end{array}$ & 21 & 75.87 & 6.28 \\
\hline \multirow[t]{4}{*}{$4^{\text {th }}$ Yea } & & 58 & 69.09 & 7.98 \\
\hline & $\begin{array}{l}\text { Ağrı İbrahim Çeçen University School for Health Sciences, } \\
\text { Nursing Department }\end{array}$ & 10 & 70.69 & 9.40 \\
\hline & $\begin{array}{l}\text { İstanbul University Bakırköy School for Health Sciences, } \\
\text { Nursing Department }\end{array}$ & 23 & 69.56 & 6.84 \\
\hline & $\begin{array}{l}\text { Mersin University School for Health Sciences, Nursing } \\
\text { Department }\end{array}$ & 25 & 65.02 & 8.53 \\
\hline
\end{tabular}




\section{Education in Medicine Journal}

2012, VOL 4 ISSUE 1

DOI:10.5959/eimj.v4i1.13

Table 4: The students' attitudes about HIV/AIDS in terms of marriage, sexual experiences, caring to HIV / AIDS person: Mean Scores and Standard Deviations ( $\mathrm{N}=230$ )

\begin{tabular}{|c|c|c|c|}
\hline Variables & $\mathbf{n}$ & Mean & SD \\
\hline \multicolumn{4}{|c|}{ Marital status } \\
\hline Married & 8 & 72.63 & 7.98 \\
\hline Single & 221 & 70.32 & 7.88 \\
\hline \multicolumn{4}{|c|}{ Sexual Experience } \\
\hline Yes & 14 & 73.64 & 7.20 \\
\hline No & 215 & 70.19 & 7.86 \\
\hline \multicolumn{4}{|c|}{ I gave care to one of the person that suffering from HIV / AIDS } \\
\hline Yes & 41 & 71.56 & 7.86 \\
\hline No & 188 & 70.14 & 7.87 \\
\hline \multicolumn{4}{|c|}{ I feel anxiety for caring one of the person that suffering from HIV / AIDS } \\
\hline Yes & 126 & 67.95 & 7.59 \\
\hline No & 103 & 73.39 & 7.18 \\
\hline
\end{tabular}

\section{Reference}

1. Turkey Ministry of Health (2011). AIDS vaka taşıyıcılarının yıllara göre dağılımı Türkiye 1985 - 2011. Availabe from URL: http://www.saglik.gov.tr/TR/istatistik/

2. The United Nations Joint Programme on HIV/AIDS \& World Health Organization (2012). AIDS epidemic update. Availabe from URL: http://www.unaids.org/en/resources/pressce ntre/pressreleaseandstatementarchive/2011/ november/20111121wad2011report/

Accessed 10 March 2012.

3. Korkmaz M. Türkiye'de nüfus artışı ve genç nüfusun eğitim sürecindeki görünümü. Milli Eğitim, 1999; 142: 63-66.

4. The United Nations Children's Fundation. Gençler arasında HIV/AIDS'I Önleme Çalışmaları. 2007. Available from URL: http://www.unicef.org/turkey/pr/_ah7.html. Accessed 5 February 2007.

5. Kutlu Ö, Tümer A. HIV/AIDS eğitim programı üzerine bir çalışma. HIV/AIDS Dergisi, 1999; 1: 24-30.

6. Kocaoğlu B, Hayran O. Level of knowledge and attitudes of touristic hotel staff towards HIV/AIDS in İstanbul. Boğaziçi Journal, 1999; 13: 181- 191.
7. Ekuklu G, Tuğrul H, Gül H, Eskiocak $M$, Saltık A. Trakya Üniversitesi Tıp Fakültesi öğrencilerinin HIV/AIDS konusundaki bilgitutumları ve 1996'dan bu yana değişimi. HIV / AIDS Dergisi, 2004; 7(4).

8. Temiz G, Batmaz M, Akhan L U, Illhan N, Özhan F, Özdilli K. Üniversite öğrencilerinin AIDS ile ilgili bilgi ve tutumları. Üniversite ve Toplum, 2005; 5(4): 1-14.

9. Duyan V. HIV/AIDS'in psikolojik boyutu. Toplum ve Sosyal Hizmet, 2001; 12, 61-76. 10. Hodgson I. Attitudes towards people with HIV/AIDS: entropy and health care ethics. JAN, 1997; 26: 283- 288.

11. Lohrmann $C$, Välimäki $M$, Suominen $T$, Muinonen U, Dassen T, Peate I. German nursing students' knowledge of and attitude to HIV and AIDS: two decades after the first AIDS cases. JAN, 2000; 31: 696-703.

12. Martin J E, Bedimo A L. Nurse practitioner, nurse midwife and physician assistant attitudes and care practices related to persons with HIV/AIDS. JAANP, 2000; 12: 3542.

13. Polgar M F. Concern, caution, and care: HIV risk perception among hospital among hospital nurses. SI, 2000; 70: 253- 279. 


\section{Education in Medicine Journal}

2012, VOL 4 ISSUE 1

DOI:10.5959/eimj.v4i1.13

14. Mbanya D N, Zebaze $R$, Kengne A $P$, Minkoulou E M, Awah $P$, Beure $M$. Knowledge, attitudes and practices of nursing staff in a rural hospital of Cameroon: how much does the health care provider know about the human immunodeficiency virus/ acquired immune deficiency syndrome?. Int Nurs Rev, 2001; 48: 241- 249.

15. Sapountzi- Krepia D, Antonakis N, Sgantzos M, Lionis C. Seeking the attitudes and perceptions of Greek primary-care professionals on voluntery work in caring for people with HIV/AIDS. JAN, 2003; 35: 683690.

16. Juan C W, Siebers R, Wu F F S, Wu C J, Chang $Y$ J, Chao $C$. The attitudes, concerns, gloving practices and knowledge of nurses in a Taiwanese hospital regarding AIDS and HIV. Int J Nurs Pract, 2004; 10: 32- 38.

17. Cornelius J B. HIV related knowledge, attitudes, and perceived risk of exposure of African-American nursing students from a high prevalence AIDS area. J Multicult Nurs Health, 2006; 12: 42- 50.

18. Oyeyemi A, Oyeyemi B, Bello I. Caring for patients living with AIDS: knowledge, attitude, and global level of comfort. JAN, 2006; 53: 196-204.

19. Tyer-Viola L A. Obstetric nurses' attitudes and nursing care intentions regarding care of
HIV positive pregnant women. JOGNN Clinical Research, 2007; 36: 398- 409.

20. Karadeniz G, Altıparmak S, Yanıkkerem E. Genç erişkinlerin HIV/AIDS'li kişilere karşı tutumları. TSK Koruyucu Hekimlik Bülteni, 2004; 3: 87- 92.

21. Kaya M, Aylaz R, Yağmur Y, Güneş G. Sağlık Yüksek Okulu öğrencilerinin HIV/AIDS'le ilgili bilgi ve tutumları. TSK Koruyucu Hekimlik Bülteni, 2007; 3: 175-180.

22. Zeren Ş G. HIV/AIDS'e Yönelik Psiko-Eğitim Programı'nın üniversiteye yeni başlayan ergenlerin HIV/AIDS'e yönelik tutumlarına etkisi. Unpublished Ph.D. Thesis, 2006, Hacettepe University, Ankara, Turkey.

23. Duyan V, il S. Attitudes of university students toward the subjects with AIDS in Turkey. HIV and AIDS Review, 2006; 5: 11-16.

24. Kılıç S, Açıkel C H, Kır T, Oğur R, Uçar M. Sağlık Astsubay Meslek Yüksek Okulu öğrencilerinin HIV/AIDS hakkındaki bilgi düzeyleri ve tutumları. TSK Koruyucu Hekimlik Bülteni, 2004; 3: 111-118.

25. Peate I, Suominen T, Valimaki $M$, Lohrmann C, Muinonen U. HIV/AIDS and its impact on student nurses. Nurse Educ Today, 2002; 22: 492-501.

\section{Corresponding author}

\section{Şerife Gonca Zeren,}

Assistant Professor.

Y1ldı Technical University, The Faculty of Education,

Psychological Counseling and Guidance,

Davutpasa, Esenler İstanbul

e-mail: goncazeren@yahoo.com 